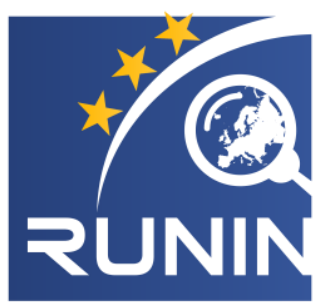

The Role of Universities in Innovation and Regional Development

\title{
Bridging the chasm? Exploring the Effect of the University Context on Knowledge Exchange
}

WORKING PAPER 01/2020

DOI: $10.3990 / 4.2535-5686.2020 .01$

Available at https://runinproject.eu/results/working-paper-series/

\section{Rhoda Ahoba-Sam ${ }^{1 *}$, Andrea Caputo ${ }^{1}$, David Charles ${ }^{2} \&$ Rebecca Herron ${ }^{1}$}

'Lincoln International Business School, University of Lincoln, UK

${ }^{2}$ Newcastle Business School, Northumbria University, Newcastle, UK

*corresponding author: rahobasam@lincoln.ac.uk

This project has received funding from the European Union's Horizon 2020 research and innovation programme under Marie Skłodowska-Curie grant agreement No. 722295. 


\section{Bridging the chasm? Exploring the Effect of the University Context on Knowledge Exchange}

\section{Abstract}

This paper provides evidence of the importance of the university context in the facilitation of academic engagement. We conceptualise universities as important actors in the innovation process, and academic engagement as encompassing knowledge-related activities occurring within and outside the university, i.e. those involving both internal and external stakeholders. Universities have increasingly been seen to engage with their communities, or at least show much interest in third mission activities. Universities have, in some cases, put on a cloak of entrepreneurship and have essentially introduced the market into academia. Academic scientists have also had to be more entrepreneurial. However, too often, a chasm is evident between the institutional efforts and the individual efforts identified - universities' engagement efforts may not always consolidate the efforts of individual academics who could be considered the actual conduits for knowledge exchange. In fact, several studies have reported that academic scientists frequently engage outside their institutions with little or no direct assistance from their universities. In our view, this has implications on the ability of universities to facilitate knowledge exchange processes. Based on 39 interviews from Sweden and the UK, we argue that enhanced management of knowledge exchange processes is imperative for facilitating knowledge exchange. Our findings have implications for university management.

Keywords: academic engagement, university context, knowledge exchange, academic scientists, Lincoln, Linköping

JEL: D8, 123, L2 


\section{Bridging the chasm? Exploring the Effect of the University Context on Knowledge Exchange}

\section{Table of Contents}

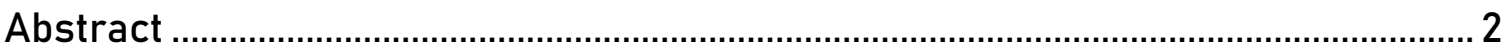

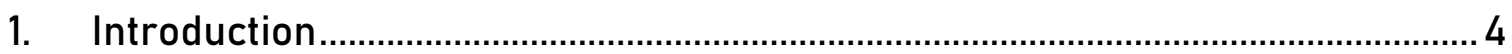

2. Universities' engagement and third mission roles ...........................................5

$A$ (dis)joint mission of engagement?........................................................................ 7

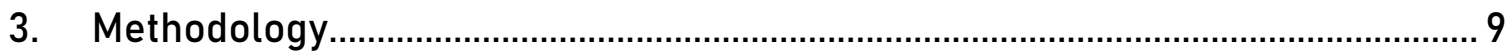

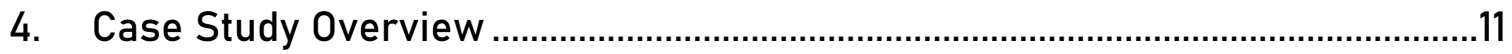

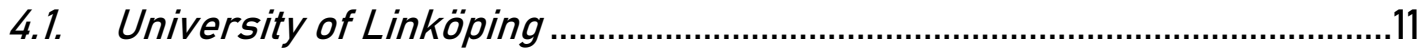

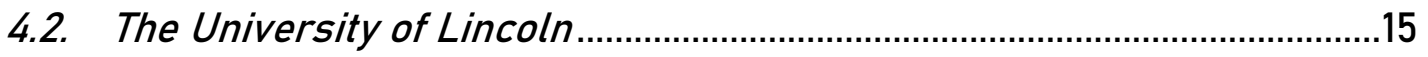

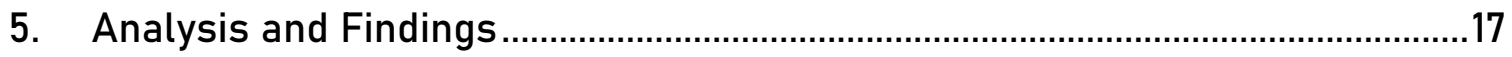

5.1. Effect of Institutional Context: Co-ordinating Collaboration ...................19

5.2. Effect of Institutional Context: Facilitating UICs........................................22

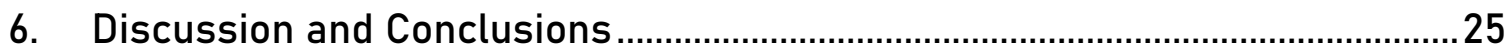

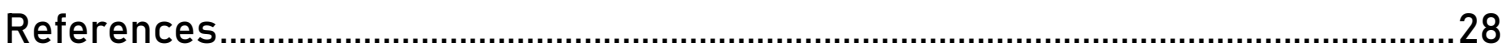

\section{List of Figures}

Figure 1: Possible intervention points for staff involvement in universities' decision making process (dotted arrows and text box refer to authors' suggestions)

Figure 2: Promotion of university-wide transdisciplinary space opportunities for knowledge exchange (authors' own emphasis)

\section{List of Tables}

Table 1: Constitution of Interviewees 


\section{Bridging the chasm? Exploring the Effect of the University Context on Knowledge Exchange}

\section{Introduction}

Worldwide, universities have been increasingly acknowledged as incubators of the capacity for social and economic growth (Arbo and Benneworth, 2007, Christopherson and Clark, 2010). As knowledge institutions, this capacity is embodied in universities' ability to contribute to the production and dissemination of new knowledge (Lambooy, 2004, Charles, 2006), as well as facilitate recombination of old forms of knowledge. Universities also advocate for collaboration with various stakeholders in their communities. This engaged outlook of universities is undertaken both locally and internationally (Trippl, 2013). By establishing and maintaining these partnerships, the flow of knowledge can be ensured. Also being linked to external partners suggests access to innovation and diversity - these present as competitive advantages for the university and their host communities.

As entities seeking to promote an agenda of impacting on their local communities (Arbo and Benneworth, 2007, OECD, 1999, OECD, 2007) universities have taken on various identities relating to their particular engagement orientation. Among these, universities can be conceptualised as entrepreneurial (Foss and Gibson, 2015, Vorley and Nelles, 2009). In being entrepreneurial, universities are embedded within regional innovation systems and have been observed to increasingly engage in commercialisation activities alongside their usual teaching and research mandate. Generally, the perceived boundaries between universities and the market have diminished (Sataøen, 2018) even as the market has been essentially been introduced into academia (Vorley and Nelles, 2009, Etzkowitz, 2003).

Individual academic scientists are central to the entrepreneurial and knowledge exchange activities of a university. Whilst top management may identify engagement as a key element of institutional strategies, it is individuals that have 


\section{Bridging the chasm? Exploring the Effect of the University Context on Knowledge Exchange}

to lead on implementation. This is especially necessary as much knowledge is tacit and embedded within the capacity of individuals. To this end, the contribution of universities to knowledge transfer to external partners results from the combination of institutional strategies and structures, and the actions of individual scientists.

In delivering on the agenda of engagement however, a disparity is evident. Universities and academics do not always work together in the most optimum way. In fact, the efforts of the university, related to coordinating the efforts of individual academics, can sometimes be viewed as disjointed. Indeed, universities have often seemed to some of their academics to be somewhat distant to their individual efforts or are felt to struggle to contribute to the knowledge exchange activities of academic scientists- thus making the individual academics' agency all-the-more important for university-industry linkage (Ahoba-Sam, 2019, Perkmann et al., 2011, Franco and Haase, 2015, Perkmann et al., 2013). In our view, this tension between individual and institutional agency creates a non-optimum environment for stimulating knowledge exchange.

Based on the above insights, this paper seeks to explore how effective universities are in fostering knowledge exchange. We focus specifically on the university structural and functional context to explore how these could promote or mitigate the prospects of knowledge exchange. We examine this through investigations of the University of Lincoln and Linköping. From Lincoln, we especially highlight the structure of the university and its effects on knowledge exchange and from Linköping, the effects of the functional and decision-making processes.

\section{Universitles' engagement and third mission roles}

Traditionally, research and education are the core missions of universities. However, various governmental reforms, have led to an increased focus on so- 


\section{Bridging the chasm? Exploring the Effect of the University Context on Knowledge Exchange}

called third mission activities - and even further, from mere research commercialisation to a more general impact mandate (Pinheiro et al., 2015, Sataøen, 2018, Gulbrandsen and Slipersæter, 2007). Universities are thus expected to not only conduct education and research, but also make economic, social and cultural contributions to their surroundings (Arbo and Benneworth, 2007, Christopherson and Clark, 2010), and are therefore considered key to the regional development process (Shaw and Allison, 1999, Goddard and Chatterton, 1999, Vorley and Nelles, 2009, Bonaccorsi, 2017, OECD, 1999, OECD, 2007, Charles, 2006).

The call to universities to interact with public and private entities, to disseminate research both to the general public and in the creation of innovations and jobs can be understood as a political ambition for exploiting universities' potential. For example, universities face pressure from policy-makers to combine an emphasis on global research excellence with a contribution to the development of the knowledge economy in their host cities (Charles, 2011, Bonaccorsi, 2017). Universities are expected to act as economic engines (Christopherson and Clark, 2010) although the legal frameworks, funding and funding mechanisms are often absent (Franco and Haase, 2015). This political ambition is also in particular evident on a European level with a stronger focus on interaction in Horizon Europe and the introduction of Smart Specialisation Strategies (S3) into Cohesion policy (Kempton et al., 2014, Vallance et al., 2018).

The impact universities can make on multiple levels, as a consequence of engagement, has garnered increased attention. For example, the REF in the UK and the Dutch SEP-system have introduced tools to measure universities' impact but seemingly there is neither a proven model for stimulating university interaction nor a 'silver bullet' for measuring the impact created (Ràfols, 2017). While universities employ various engagement models, it is important to note that each university is unique. In particular, rural and peripheral universities struggle 


\section{Bridging the chasm? Exploring the Effect of the University Context on Knowledge Exchange}

with issues of scale and scope (Charles, 2016) which require that universities adapt differentiated mechanisms to make meaningful contributions to their communities. As players in regional innovation ecosystems, universities need to assess their strengths and weaknesses in order to come up with the appropriate strategies that can benefit their respective missions.

Universities' interactive processes are particularly often complex and the knowledge forms and approaches varied (Jonsson et al., 2015). The variety of knowledge partners encountered by universities is further compounded by diverging cultures, motives standards and values (Plewa et al., 2013, Nooteboom, 2002) which requires strategizing to navigate. Particularly in the case of University-Industry collaboration, researchers and industrialists are aligned to different incentive structures, organizational environments and cultures (Bruneel et al., 2010, Jonsson et al., 2015). Bruneel et al. (2010) further explain the need to focus on the organizational provisions designed to enhance the work of research communities - this is especially relevant because while the number of projects traversing multi-disciplinary partners have markedly increased, no corresponding understanding of such new collaborative models have been realised to enhance management of the collaborations (Corley et al., 2006, Muscio and Vallanti, 2014). Indeed, understanding the variety of drivers and barriers to universities' collaborations is key to successful knowledge transfer (Siegel et al., 2003, Plewa et al., 2013)

\section{A (dis)joint mission of engagement?}

Individuals are key to knowledge exchange (Stuck et al., 2016, Coe and Bunnell, 2003). As knowledgeable individuals, academic scientists are instrumental in the generation, transmission and optimization of new knowledge in industry. This is the case because much of the knowledge exchanged in the process of innovation is usually found in tacit form, and resides in individuals (Polanyi, 1967, Fischer and 


\section{Bridging the chasm? Exploring the Effect of the University Context on Knowledge Exchange}

Varga, 2003, Stuck et al., 2016). Given the difficulty of communicating tacit knowledge, geographical proximity is made even more important in order to increase the likelihood that knowledgeable individuals are encountered. Hence, proximity matters for the transfer of knowledge of a tacit nature (Torre, 2008, Boschma, 2005, Vlajcic et al., 2019).

Individuals are able to identify, and engage with their organisational settings based on personal factors, commitments and vantage points (Clegg, 2005). In the case of academic scientists' engagement practices, such pertinent factors include personal motivations and advancement of research goals (D'Este and Perkmann, 2011, Perkmann et al., 2011, Perkmann et al., 2013, Schillebeeckx et al., 2016). Additionally, the quality of peers (Tartari et al., 2014) and university research quality (Perkmann et al., 2011, Fitjar and Gjelsvik, 2018) impose some effects on engagement. As such, context is important for individuals' agency. However, though the immediate environment - the university environment in this case affects engagement, we align with the view that the individual is often able to resist, deny and even transcend their context (Zahle, 2016).

Existing research suggests that individual academic scientists mostly engage due to personal motivations, with little or no active support from their host universities (Ahoba-Sam, 2019, D'Este and Perkmann, 2011, Franco and Haase, 2015, Perkmann et al., 2013). Whilst institutions undoubtedly do support this engagement, the types of support are varied and perceived to different degrees (Bruneel et al., 2010) - by providing time for research and engagement activities inside the working life of academics and (albeit sometimes passively) sanctioning such activities, the level at which institutions directly support and co-ordinate engagement activities differs. In some cases, individuals have reported feeling that they work in a semi-autonomous way within their institutions. This level of coupling/de-coupling deserves some further research attention, as it appears 


\section{Bridging the chasm? Exploring the Effect of the University Context on Knowledge Exchange}

paradoxically to be both a limiting and a facilitating feature of academic engagement.

\section{Mothodology}

This paper aims to explore how the university context (i.e. structural and functional) affects knowledge exchange processes. The structural context is employed to refer to the internal organisation of the University (i.e. into faculties, schools, etc.) whereas the functional context refers to the decision-making processes employed within the university. The study employs a case study design in order to conduct a contextual study (Saunders et al., 2016), of a contemporary phenomenon, of a 'how' nature, and over which investigators have no control (Yin, 2002, Wilson, 2014). We further employ a qualitative study approach in order to obtain in-depth insight (Yin, 1984) into a social phenomenon in which subjects are individuals (Bryman, 1984). By employing a semi-structured interview approach, we try to understand interviewees in their own words (Chowdhury, 2014).

Specifically, empirical data was obtained through semi-structured interviews with selected academic scientists, collaboration staff and industry partners from the University of Lincoln, UK and University of Linköping, Sweden. In all, 39 interviews were carried out as shown in the Table 1. 18 of them were from the UK whereas the remaining 21 were from Sweden. Most interviews took up to 45 minutes and were recorded with the permission of interviewees. Of the Swedish sample, 8 interviewees were academic scientists whereas the remaining 19 were collaboration staff' ${ }^{1}$ with 2 of them being top management personnel. 12 academic scientists, 4 industrialists and 2 collaboration staff made up the UK sample.

\footnotetext{
${ }^{1}$ Collaboration staff as used in the Swedish sample refers particularly to the members of the team of 'Collaboration-Co-ordinators', a.k.a Samverkanskoordinators (Swedish).
} 


\section{Bridging the chasm? Exploring the Effect of the University Context on Knowledge Exchange}

Academic Scientists were selected from STEM disciplines; where engagement is prevalent (Perkmann et al., 2013).

Table 1: Constitution of Interviewees

\begin{tabular}{|l|l|l|c|l|}
\hline $\begin{array}{l}\text { Sweden } \\
18\end{array}$ & $\begin{array}{l}\text { University of Linköping } \\
(21 \text { interviewees })\end{array}$ & $\begin{array}{l}\text { Engaged academic } \\
\text { scientists in STEM }\end{array}$ & 8 & $\begin{array}{l}\text { Interviewee LiU1 - } \\
\text { interviewee LiU8 }\end{array}$ \\
\hline & Collaboration staff & 10 & $\begin{array}{l}\text { interviewee LiU9 - } \\
\text { interviewee LIU18 }\end{array}$ \\
\hline $\begin{array}{l}\text { UK } \\
18\end{array}$ & $\begin{array}{l}\text { University of Lincoln } \\
(18 \text { interviewees })\end{array}$ & $\begin{array}{l}\text { Engaged academics in } \\
\text { STEM }\end{array}$ & 12 & $\begin{array}{l}\text { interviewee UoL1- } \\
\text { interviewee UoL12 }\end{array}$ \\
\hline & & Firm partners & 4 & $\begin{array}{l}\text { interviewee UoL13 - } \\
\text { interviewee UoL16 }\end{array}$ \\
\hline & & Collaboration staff & 2 & $\begin{array}{l}\text { interviewee UoL17 \& } \\
\text { interviewee UoL18 }\end{array}$ \\
\hline
\end{tabular}

These cases rather than forming a basis for comparison, are presented as case examples of the university context. Together, the two cases contribute to a deeper understanding of how universities' systems could promote or mitigate the possible exploitation of knowledge exchange processes. While the particular case of Lincoln is used to demonstrate the effects of universities' structural context, the case of Linköping emphasises the effect of the functional context. The two cases were interesting choices for this study based on their common characteristics of being young and peripherally located and thus presented a unique perspective for studying regional engagement. Further these cases were accessible to investigators ${ }^{2}$.

Generally, the interviews were focused on understanding collaboration from the university context. The academics in the interview sample were asked questions about their collaboration practices (especially with industry partners) and the

\footnotetext{
${ }^{2}$ The cases presented are also studied as part of in-depth investigations of the RUNIN Project research (see https://runinproject.eu/).
} 


\section{Bridging the chasm? Exploring the Effect of the University Context on Knowledge Exchange}

support provided by their institutions. We probed the institutional requirements for third mission activities, the types of collaborators they interacted with and if those contacts were institutionalised. For the collaboration staff, we tried to understand their role in supporting third mission activities and what challenges they faced. Because interviews were typically semi-structured, interviewees were allowed to speak broadly on the subject of collaboration from their own experiences. The data collected was later transcribed and analysed. In order to obtain a holistic view for the given context, interviews were analysed singularly and later synthesized. Interviewees in this narration have been coded to protect their anonymity.

\section{Case Study Overvlew}

\subsection{University of Linköping}

The University of Linköping (aka Linköpings universitet, LiU) is located in the Östergötland region of Sweden. The campus was established in the 1960's as a branch campus of Stockholm University. However in 1975, campus Linkoping attained its independence and is today made up of four campuses; Campus Valla, Campus US, Campus Norrköping, Campus Lidingö. The university pursues research and postgraduate studies in fields such as technology, medicine, and humanities, natural, educational, social and behavioural sciences, and is distinguished in materials science, IT and the science of hearing. LiU is particularly acclaimed for its multidisciplinary research and was from 1980, the first Swedish University to introduce interdisciplinary thematic research at the Faculty of Arts and Sciences, and a cross-subject, interdisciplinary perspective in graduate schools for PhD students. ${ }^{3}$

\footnotetext{
${ }^{3}$ Facts about LiU collected from University's website at https://liu.se/en/about-liu
} 


\section{Bridging the chasm? Exploring the Effect of the University Context on Knowledge Exchange}

Though the Östergötland region is largely agricultural, its two main cities of Linköping and Norrköping, have in particular successfully attracted important and diverse industrial activities and knowledge-intensive companies (GermainAlarmatine, 2018). Notable of the industries located in Linköping are Saab AB and Ericsson. In close proximity to the LiU campus at Valla is the Science Park Mjärdevi, which houses a community of university collaborators and is an important source of innovation to the region (Feldman, 2007, Hommen et al., 2006).

Collaboration is not a strange concept to LiU. In fact, the university prides itself on a reputation of engagement which is often described as being engraved in the universities' DNA. Specifically, Peter Värbrand (Deputy Vice-Chancellor for External Relations and Innovation) explains: 'Collaboration is a crucial factor for our success and a means to make research and education even more competitive: it is a part of LiU's soul' 4

By way of partnerships, the University, as an organisation, has established partnerships with several of the companies in the region. Notable among these are the so-called 'Strategic partners'. These partners are long trusted companies and public bodies with whom the university has entered into agreements, intending to deepen collaboration. The aim here is to strategically 'secure future needs for expertise, and create benefit through collaboration in research and innovation'4. According to Jan Axelsson (Director of Collaboration, Linköping University):

'The ultimate goal of our education and research is to promote the development of society. A highly developed strategy for collaboration is one of the conditions required for this to happen. ${ }^{4}$

${ }^{4}$ https://liu.se/en/collaboration (accessed 18.10.19) 


\section{Bridging the chasm? Exploring the Effect of the University Context on Knowledge Exchange}

\section{Co-ordinating Collaboration}

In 2014, LiU initiated an exercise to collect and document impact cases across the university. This exercise was linked to some state funding accessed through VINNOVA, the state's research institute. The exercise was understood by many as similar to the UK's REF format of assessing research impact through collection of impact cases. The management staff in charge of this exercise decided to document academic engagement across the university - however for LiU, this was a new initiative that would take time to develop and perfect. The project was rolled out by appointing some staff into the role of 'Collaboration co-ordinators' (CCs), as translated from the original Swedish title of 'Samverkanskoordinators'.

The CCs (about 22 in all), were selected from across the universities' various departments and faculties. Further, most of them were academic scientists at varying levels in their academic careers. Though the specific requirements for inclusion are quite unclear, being a researcher or academic was not necessarily a prima facie case for one's selection. Indeed, staff availability and interest in participating, seem to have received much consideration. Though from the outset the specific role was not explicitly explained to the selected collaboration staff,

It [the role] was not so well defined for me, as I recall. I think that the persons that suggested me and asked me if I wanted to be the representative for this department, probably didn't know so much about what it would entail [....] I don't think it was so clear for the persons that were organizing it either'. Interviewee LiU17

Among the CCs, documenting academic impact cases was indeed the general understanding of the purpose of the appointment. The CCs therefore went about exploring the role in different ways, as for example: 


\section{Bridging the chasm? Exploring the Effect of the University Context on Knowledge Exchange}

[...] we started out mainly by trying to find these impact cases and to come up with a pool of impact cases for the university that were representative for what we were doing. So we spent most of our time doing that actually during the first period maybe, I don't know, one and a half years or so.' Interviewee LiU9

Initiating the CCs role was probably a good way to create awareness of research impact across the universities. In some departments, where collaboration was already more pronounced, the CCs were more easily able to document impact cases. In those departments of more theoretical focus, there was more challenge in assessing impact - some of the academics here perceived impact to be most relevant with industry collaborations and would not consider other forms of collaborations relevant for the exercise. Some academics were also careful not to say too much about their collaborators. Further, even though some of the CCs had entered the role with some ideas to develop the role for the benefit of the University, the universities' management seemingly did not take advantage of these views.

Subsequently, it appeared that the role was only initiated in fulfilment of a funding requirement such that, after collection of the cases, the fate of the group of CCs was uncertain. This is exemplified as follows:

'It felt like this is another report that they should use so they were asking for this kind of impacts projects - projects with impact. So okay let's provide some information to them and then it's done. I mean we provide different kinds of reports to the financier over and over again. And I know it was some kind of information needed by the university and it's done' Interviewee LiU18

Indeed, while LiU is a university of a long tradition of collaboration, universities face some inherent challenges in initiating, managing and co-ordinating collaboration and knowledge exchange-activities. Those identified challenges linked to the case of the CCs will especially be discussed in the next section. 


\section{Bridging the chasm? Exploring the Effect of the University Context on Knowledge Exchange}

\subsection{The University of Lincoln}

The University of Lincoln (UoL) is a relatively young university located in Lincolnshire in the East Midlands of England. The University started as a series of small colleges based in Hull which came together to form the Hull College of Higher Education in 1976. The main campus was eventually moved to its present location of Lincoln in the 1990s, after a series of restructuring and moves. Today, UoL operates as a full-range university (Charles, 2016) from three campus sites; Brayford Pool (main campus), Holbeach and Riseholme.

The University has always identified with supporting the local economy seeing its mission as an anchor institution. The university is well-connected to the society, and according to Regeneris Consulting (2017), the university supports more than $5 \%$ of all jobs in Lincoln, and more than 1 in every 6 working age residents in the city is either a student, a direct employee or their job is indirectly linked to the University. UoL plays an important role in the regional innovation process and responds to regional economic needs through collaborating with local businesses such as Siemens, and serving the large regional food manufacturing sector through the National Centre for Food Manufacturing (NCFM) at the Holbeach campus (Ahoba-Sam et al., 2018, Birch et al., 2013). The University states that 'The unique relationships with companies such as Siemens and the Lincolnshire Co-op demonstrate the university's innovative industry-engaged approach $^{5}$

Considerable investment has targeted the provision of state-of-the-art research facilities that have contributed to the University's success - in attracting highquality staff, creative and productive students, and successful business collaborations. According to Professor Andrew Hunter, Deputy Vice Chancellor:

${ }^{5}$ https://www.lincoln.ac.uk/home/businessengagement/industrylinks/ (accessed 22/10/19) 


\section{Bridging the chasm? Exploring the Effect of the University Context on Knowledge Exchange}

'The University is committed to developing research and scholarship that fosters a vibrant culture in which to work and study. As this dynamic culture grows, research begins to infiltrate everything we do -enhancing partnerships, improving interdisciplinary thinking and, in turn, making a visible contribution to wider society $^{\prime 6}$

The university prides itself in the ability to understand and respond to the needs of business: engaging with industry experts to address specific skills gaps by launching new academic programmes and pursuing cutting-edge research to solve real-world commercial challenges. In 2017, Lincoln was one of only eight UK universities to be commended by the Higher Education Funding Council for England for its strategic approach to knowledge exchange ${ }^{7}$

\section{Facilitating UICS}

One way the University of Lincoln encourages engagement with industry is by creating platforms through which academic scientists and industrialists can work together. Such platforms range from informal networking events to structured committee memberships. The LIBS Connect Event and Ignite ${ }^{8}$ are examples of such opportunities to bring both university staff and external collaborators together. The Connect event is aimed at facilitating interactions between the business community and the Lincoln International Business School. Ignite, which is hosted by Sparkhouse, the University's incubation centre for start-up companies provides a range of opportunities to engage with small businesses.

Another type of platform is the inclusion of industry partners in the university's various committees and steering groups. The Industry Digitalisation ${ }^{9}$ agenda of

\footnotetext{
${ }^{6}$ https://www.lincoln.ac.uk/home/researchatlincoln/researchenvironment/ (accessed 22/10/19)

${ }^{7}$ https://www.lincoln.ac.uk/news/2017/07/1380.asp (accessed 22/10/19)

8 https://www.lincoln.ac.uk/home/businessengagement/networkingandevents/ (accessed 22/10/19)

9 https://www.lincoln.ac.uk/news/2018/01/1429.asp (accessed 22/10/19)
} 


\section{Bridging the chasm? Exploring the Effect of the University Context on Knowledge Exchange}

the University is one example of such platforms that brought together both academic staff and industrialists - this time, with the aim of developing a new digital skills curriculum to serve the innovation needs of major industries ranging from food manufacturing to renewable energy. According to Professor Libby John, Pro Vice Chancellor and Head of the College of Science at the University of Lincoln:

'Society is in the midst of a Fourth Industrial Revolution and those economies which thrive in the 21st Century will be those that embrace digitally enabled technologies, such as robotics, machine learning, the Internet of Things and big data analytics'; 'Lincolnshire is in prime position to build on its strengths in sectors such as food and farming, engineering and tourism - if we can establish the infrastructure needed to realise the full potential of digital to enhance productivity and deliver real innovation. Digital literacy of the current and future workforce will be a crucial component and this project directly addresses that need, working hand-in-hand with employers's

The Industry Digitalisation steering group ${ }^{10}$, served as a first-hand experience at how universities and industry can come together for achieving a common aim. However, even for a university that is closely knit to the local society and businesses, there are challenges in facilitating UICs. We highlight some of these challenges in the next section.

\section{Analysis and Findings}

The data collected from both Linköping and Lincoln show that some academics are wanting greater institutional support for their external engagement. Even

\footnotetext{
9 https://www.lincoln.ac.uk/news/2018/01/1429.asp (accessed 22/10/19)

${ }^{10}$ One of the authors observed a meeting of the Industry Digitalisation Steering Group, and interacted with its members on 09.04.19.
} 


\section{Bridging the chasm? Exploring the Effect of the University Context on Knowledge Exchange}

though universities have increasingly shown interest in engagement, and actually expect academic scientists to engage, individuals often act independently. This means those academic scientists who find engagement appealing do so more out of intrinsic rather than extrinsic reasons. As explained by academics in this study, even though their institutions have a history of engagement, support for their external engagement could be further developed. For example:

'[....] I cannot say that I get any active support [.......], I cannot say that the university is actively helping us to have a broader network. They are more expecting us to do it but they're not giving us any actual resources to' Interviewee LiU4

[...... but there's no time allocated for writing the grants, there's no budget put together for writing the grants. You are expected to do it along with all the teaching'. Interviewee UoL2

Further, it was apparent that efforts of university leaders to engage externally were sometimes carried out without the knowledge or support of academics who might actually be required to nurture the relationships. 'But now they are more running around talking with the industry, and sometimes it becomes little bit embarrassing because they have been out discussing about collaboration with companies that we already collaborate with'Interviewee LiU4

Decisions were made in a 'top-down' fashion that did not always reflect academics' preferred modes of engagement. When the support was offered, it was not done in the right way. Rather than a facilitator role, the universities' management appeared to require a 'lead role in the engagement. Academics were thus reluctant to share their contacts, or important contacts for fear of the university 'messing up' their contacts. The academics argued, 'contacts can be shared, but not relationships. Academic scientists argued that, it was necessary for trust to be established between universities' management and individual 


\section{Bridging the chasm? Exploring the Effect of the University Context on Knowledge Exchange}

academic scientist. But would academics share their individual contacts? '/t depends on the way they're asking it. I mean if they're just coming and asking we would like to have a contact persons, no [......] If we can have a discussion and they're asking "How can we support it? What can we do for you? Then we can build up trust Interviewee LiU4

The kind of support required by Academic Scientists may not be those offered by the University -in which case there is a perceived lack of support. An interviewee (LiU3) highlighted needed support in 'basic things' such as 'or-organizing meetings with companies and...support writing applications with companies'. This was also emphasized in the following:

'But in order to get a good industry collaboration between university and industry you need to have more bottom-up, so maybe what universities should focus on is not try to take, they should instead facilitate; [......] because maybe they're running around meeting some companies, but they should be more focusing on going and walking around in the corridors, asking and discussing with us what need and do you have any need for collaboration or how can we support your collaboration? Interviewee LiU4

\subsection{Effect of Institutional Context: Co-ordinating Collaboration}

The case of collaboration management in Linköping offered some insight into how decision-making within universities could enhance or deter knowledge exchange. Though setting up a group of staff in the name of collaboration co-ordinators held much potential, the group's potential was probably not maximised. The staff, because they belonged to the same role, formed a network of individuals across the university who were interested in engagement and lessons from across the university were shared across the board and carried back to the respective departments. This network was in many respects crucial for internal development 


\section{Bridging the chasm? Exploring the Effect of the University Context on Knowledge Exchange}

of the knowledge-exchange capacity of the university. Despite a good initiative, some challenges were evident.

In the first instance, it emphasizes the top-down decision-making tendency of university management as emphasized in a top management decision of how to roll-out and facilitate collection of impact cases, and an unclear role for the selected co-ordinators. As explained, '[the role] has changed a lot..... when we started it was not clear from the start what we were going to do. So we had to develop the role while working on different things'. Interview LiU9

Top management decision-making on issues of engagement is not necessarily wrong. However at a point, it is beneficial that the views of individuals involved in these processes are solicited. According to the senior management staff who spear-headed the exercise, there was indeed uncertainty at the beginning of the exercise 'We didn't know that from the start'LiU14, however this might have been good for developing the role, '[.....] looking back, I think it was kind of wise anyway not saying this is exactly what you should do' LiU13. Accordingly, this apparent lack of direction for the CCs might have offered much flexibility in the given role. Rather than a disadvantage, the flexibility could be viewed as a good opportunity to also solicit the views of individual CCs on how the role could develop into something that could facilitate academic engagement, but this was not the case.

Consequently, some academics seemed disappointed in the fact that their 'expertise could not be utilised'to optimise the role. For example, one of the CCs suggested that, the management appeared more interested in collecting exemplary cases of collaboration rather than actually promoting collaboration

'I consider myself to be good at communicating in written form to various target groups. So I think maybe I got the impression that it could be more about that, about actually writing about what was going on, but it turned out to be not so much of that. We were mainly collecting texts.... the reason I had that impression is that since 


\section{Bridging the chasm? Exploring the Effect of the University Context on Knowledge Exchange}

I'm not actually doing these kind of collaborative projects, the reason for selecting me [was] my competence'. Interviewee LiU17

The CCs faced some further challenges in coming up with cases from their departments, especially in those fields where research was more theoretical than applied. When they succeeded in bringing out cases, these were not selected as exemplary cases, which according to them was because they did not involve industry. This buttressed a general view that only those academic scientists who collaborate with industry can be classified as 'engaged' - unfortunately, this was seen as being supported and reflected in the cases selected by the university.

'So that was our main focus in the beginning, and of course I should say the role is of course very different at different departments. Some departments have been collaborating with industry forever, so this is business as usual for them, right? For us it's not so. I mean we have some parts which have been collaborating a lot, but that's a small part. So we don't naturally have contacts with industry so my role was not so much sort of mediating collaborations and so on, but I had more, role of informing and also from both directions right to taking the viewpoints of the staff back to the central meeting and the other way around and doing these impact cases' Interviewee LiU9.

At the end of the interview period, the collaboration staff were even more uncertain what their role would be, given some re-organizations in the university regarding the structure of collaborations. 'And now it is sort of changing again because the structure at the university is changing so now I don't know really what's going on. Because they have changed the whole organization for collaborations and all these things at university'Interviewee LiU7. However, some CCs obviously had some ideas they were (still are) willing to contribute as interventions towards what their roles could be in the light of the changes. 


\section{Bridging the chasm? Exploring the Effect of the University Context on Knowledge Exchange}

As a contextual example captured at a particular time, this example especially highlights how universities' management could better involve lower management staff and other individuals within universities in decision-making processes as suggested in Fig. 1 below. Here we do not necessarily promote a bottom-up decision making process over a top-down approach, but rather emphasise a more inclusive process of both top- and lower-level decision makers.

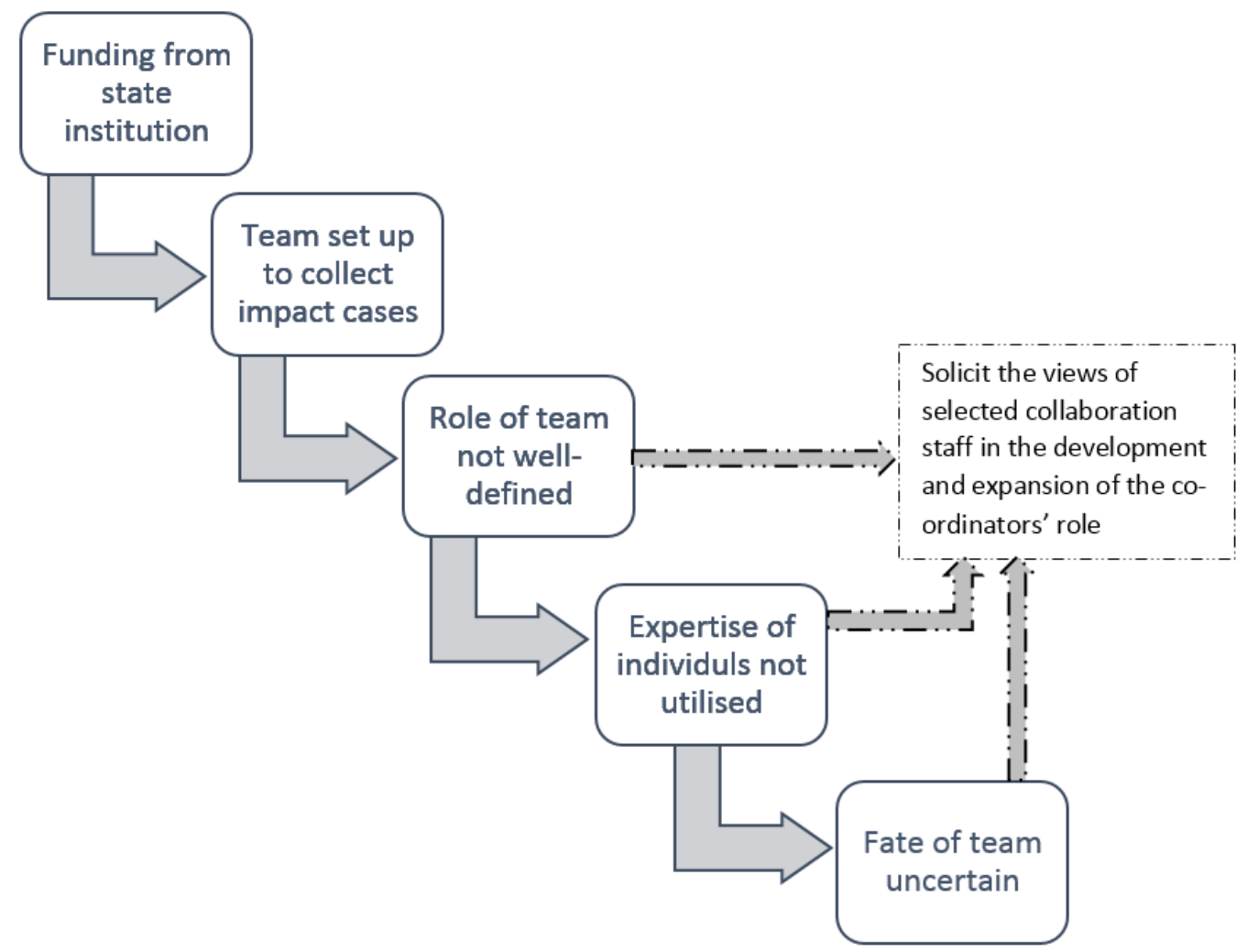

Figure 1: Possible intervention points for staff involvement in universities' decision making process (dotted arrows and text box refer to authors' suggestions)

\subsection{Effect of Institutional Context: Facilitating UICs}

The Lincoln case further highlights how the 'structural' context of the university could affect knowledge exchange processes. Organisation of universities into different faculties and colleges is, at best, a strategic decision which enables easy management and co-ordination. However, placed under the lens of knowledge 


\section{Bridging the chasm? Exploring the Effect of the University Context on Knowledge Exchange}

exchange processes, universities' structures may sometimes deter knowledge exchange.

Internally, the decided location of academic scientists is a determinant of who they [academics] could possibly collaborate with. Placement of academics in different colleges, schools or faculties mediated their engagement opportunities. As highlighted by an interviewee:

'The university decides on the structure of the departments and where the departments lie, both geographically and administratively (bureaucratically).....so it is difficult to know what another reality would look like...for instance if a person from architecture held a place in this department, maybe as a structural engineer I would know that person, would know their capabilities and would make a great relationship with them, but you just never know'. Interviewee UoL6

A possible way to counteract the effect of this compartmentalisation is the presentation of meeting opportunities for staff across the universities. However, the present efforts were considered ill-mediated and not well-structured opportunities. This was emphasized as follows:

'[....] if the university wanted to help us meet people, then they would think more structurally about what is the research group, who works in the research group, what does the research group look like from the outside, how can the research group be more visible, how can the research group influence other 'departments' of the university more, doesn't mean we have to change our structure.....' Interviewee UoL6

Externally, the university structure is perceived by some industry partners as a 'silo-structured', contrasting the typical hierarchical structure of industry. This silo situation makes contacting the right person for a particular collaboration 


\section{Bridging the chasm? Exploring the Effect of the University Context on Knowledge Exchange}

difficult. This was buttressed in the following about the digitalisation steering group;

'That one (the digitalisation steering group) has gone across the University campus more than others, but it's quite a thin link. I now know some people. I barely know what most of them do, apart from the ones I already knew. We don't meet very often and when we do, we've got a particular intent, which is around a core activity of industrial digitalization. I'm happy to help with that....I'm interested in it because it will impact on our business but in terms of a networking opportunity. It's not a great networking opportunity'. Interviewee UoL15

Further, external collaborators are burdened with the problem of who to contact for a particular assistance due to the university's structure. An academic researcher highlighted this issue on the difficulties encountered by prospective external links while suggesting an improvement in the university's marketing strategy, '[.....] When you hear 250 companies and see a maximum of 10, there are lots of missing ones. I think it's a missed opportunity [....] Interviewee UoL1

Being on universities' committees is seen as a good means of facilitating knowledge exchange. However, because industry research is of a more 'transdisciplinary' type, industrialists end up sitting on too many university committees which end up being 'time-consuming'.

In all, promoting meeting opportunities for university staff could be a good way of overcoming internally-faced structural challenges to knowledge exchange. If these provisions can be successfully extended to university-wide, interdisciplinary events that attract potential external [industry] partners, as well as existing external partners, as highlighted in Fig. 2 below, the challenges presented by the university structure could be mitigated. 


\section{Bridging the chasm? Exploring the Effect of the University Context on Knowledge Exchange}

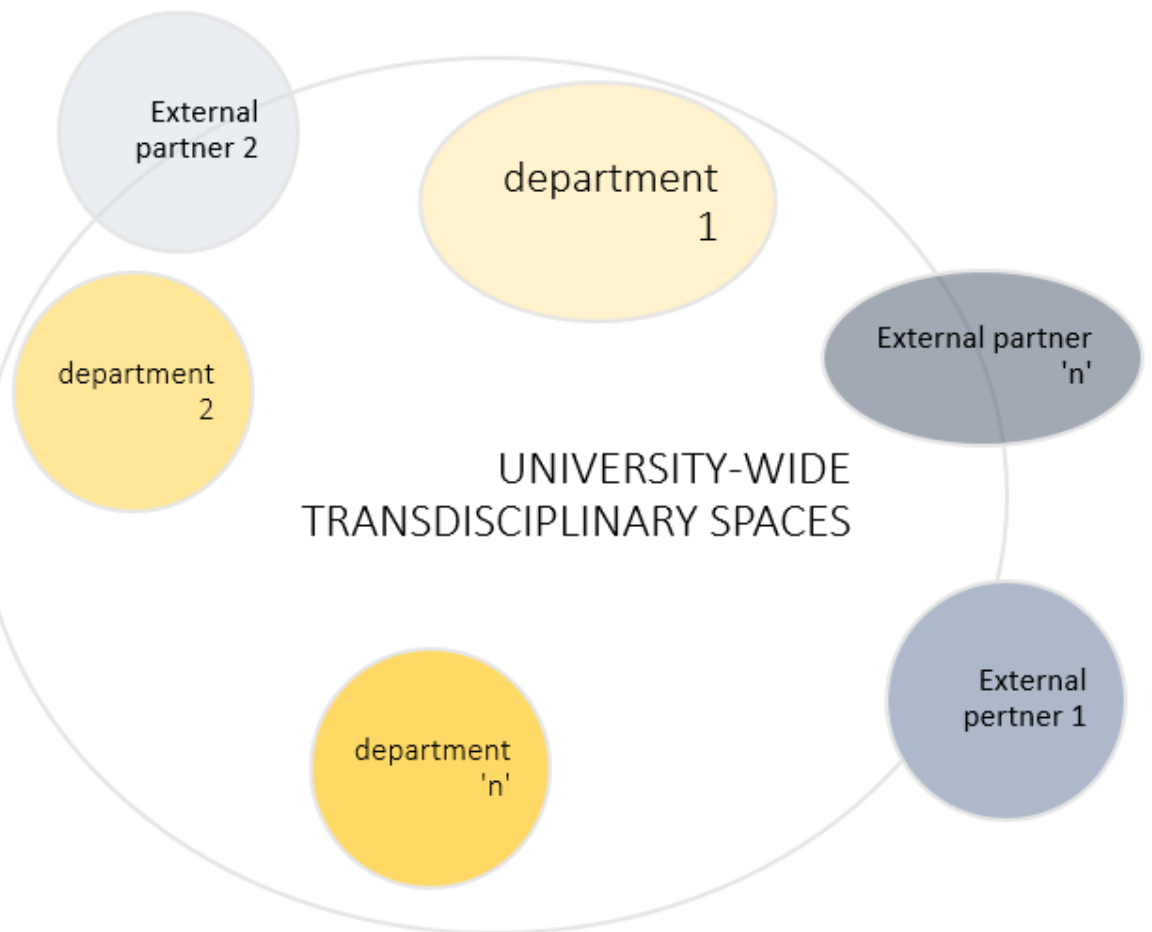

Figure 2: Promotion of university-wide transdisciplinary space opportunities for knowledge exchange (authors' own emphasis)

The need for such transdisciplinary spaces has been identified by the university (UoL) centrally and discussed at meetings of the university professoriate, but it has proved difficult to develop new cross faculty/cross school institutes. Identifying themes around which academics can coalesce is one problem, but then the identification of leadership and resourcing such institutes is an additional problem.

\section{Dlscusslon and Concluslons}

This paper sheds light on how universities could facilitate academic engagement through the management of knowledge exchange activities. By employing a qualitative approach and drawing on interviews from individuals within and outside the case universities, we show that universities experience some struggles in managing and facilitating internal knowledge exchange processes. After years of heightened focus and interest in universities' third mission 


\section{Bridging the chasm? Exploring the Effect of the University Context on Knowledge Exchange}

activities, our data shows that universities continue to struggle with the specification of engagement and mechanisms for co-ordinating engagement. Further, a lack of (adequate) institutional support for academics' external engagement activities, and the apparent absence of dialogue between university management and their engaged academic scientists suggests a chasm that needs addressing.

From our data, it is evident that universities engage in top-down decision making which does not necessarily always reflect the aspirations of individual academic scientists. These top-down decisions are further not well communicated and seemingly not debated upon to achieve the best model. We argue that though making decisions at the top management level is necessary and cannot be eliminated, there is the need for decision making on third mission activities to be as inclusive of the various stakeholders as possible. Additionally, the structuring of universities into faculties and departments does not always match those of external stakeholder organisations. So while these structures promote smooth running of universities, it imposes a challenge for prospective and active partners who either struggle to contact the right persons or dawdle with too many contacts from the same university. As suggested in this paper, one possibility to overcome this is for university-wide organization of university interaction cutting across faculties, departments, research groups and individual researchers. Additionally, there is a need for establishing different supporting mechanisms regarding engagement in consultation with individual academic scientists and other relevant stakeholders.

As emphasized by Gunasekara (2006), the various dilemmas faced by universities and academics embarking on (regional) engagement are not unknown and indeed common to any change programme. However, weighing the benefits of knowledge exchange to the regional economy (Ferreira et al., 2017), there is great incentive on addressing these dilemmas. From this study, we particularly draw attention to 


\section{Bridging the chasm? Exploring the Effect of the University Context on Knowledge Exchange}

the need for a concerted effort between institutional managers of engagement and individual academics on delivering on their third mission mandate. We especially place emphasis on dialogue that would promote the opportunity for individual academics to express the types of assistance they require in a more inclusive, and trust-building decision-making process. Further, we suggest that an increased focus on transdisciplinary spaces, accessible to both internal and external stakeholders of the university, is key to bridging the perceived chasm between universities' management and individual academic scientists.

This study indicates that there is interest from both Higher Education Institutions, through their 'academic management', and the individual academics who work in them to engage with industry partners and to share knowledge. There is also an understanding from both the institutional point of view and the individual point of view that these interactions are an important part of the contemporary vision of the role of Higher Education and both recognise these engagements as an important part of the processes - that, either intentionally or unintentionally, help create the environment that supports knowledge exchange.

The research also illustrates the way initiatives at the institutional level can often find themselves competing, or at least not aligning easily, with the micro level activities of individual academics. Perhaps more interestingly, both groups of actors have expressed awareness of this misalignment. Despite this, both coexist inside the operating environment and through their interactions create multiple possibilities for knowledge exchange. This paper therefore makes some tentative suggestions about how individual academics and academic institutions (academic management) could improve their practice, and indeed in both universities studied there is evidence of several new initiatives aimed at doing this. 


\section{References}

AHOBA-SAM, R. 2019. Why do academics engage locally? Insights from the University of Stavanger. Regional Studies, Regional Science, 6, 250-264.

AHOBA-SAM, R., SALOMAA, M. \& CHARLES, D. 2018. On Overcoming the barriers to Regional Engagement: Reflections from the University of Lincoln (RUNIN Working Paper Series; Vol. 2018, No. 04).

ARBO, P. \& BENNEWORTH, P. 2007. Understanding the Regional Contribution of Higher Education Institutions, OECD Publishing.

BIRCH, E., PERRY, D. C. \& TAYLOR, H. L. 2013. Universities and anchor institutions. Journal of Higher Education Outreach and Engagement, 17, 7-15.

BONACCORSI, A. 2017. Addressing the disenchantment: universities and regional development in peripheral regions. Journal of Economic Policy Reform, 20, 293-320.

BOSCHMA, R. 2005. Proximity and Innovation: A Critical Assessment. Regional Studies, 39, 61-74.

BRUNEEL, J., D'ESTE, P. \& SALTER, A. 2010. Investigating the factors that diminish the barriers to university-industry collaboration. Research Policy, 39, 858-868.

BRYMAN, A. 1984. The Debate about Quantitative and Qualitative Research: A Question of Method or Epistemology? . The British Journal of Sociology, 35, 75-92.

CHARLES, D. 2006. Universities as key knowledge infrastructures in regional innovation systems. Innovation: The European Journal of Social Science Research, 19, 117-130.

CHARLES, D. 2011. The role of universities in building knowledge cities in Australia. Built Environment, 37, 281-298.

CHARLES, D. 2016. The rural university campus and support for rural innovation. Science and Public Policy, 43, 763-773.

CHOWDHURY, M. F. 2014. Interpretivism in Aiding Our Understanding of the Contemporary Social World. Open Journal of Philosophy, 4, 432-438.

CHRISTOPHERSON, S. \& CLARK, J. 2010. Limits to 'The Learning Region': What University-centered Economic Development Can (and Cannot) do to Create Knowledge-based Regional Economies. Local Economy, 25, 120-130.

CLEGG, S. 2005. Theorising the mundane: The significance of agency. International Studies in Sociology of Education, 15, 149-164.

COE, N. M. \& BUNNELL, T. G. 2003. 'Spatializing' knowledge communities: towards a conceptualization of transnational innovation networks. Global Networks, 3, 437-456.

CORLEY, E. A., BOARDMAN, P. C. \& BOZEMAN, B. 2006. Design and the management of multiinstitutional research collaborations: Theoretical implications from two case studies. Research Policy, 35, 975-993.

D'ESTE, P. \& PERKMANN, M. 2011. Why do academics engage with industry? The entrepreneurial university and individual motivations. The Journal of Technology Transfer, 36, 316-339.

ETZKOWITZ, H. 2003. Research groups as 'quasi-firms': the invention of the entrepreneurial university. Research Policy, 32, 109-121.

FELDMAN, J. M. 2007. The Managerial Equation and Innovation Platforms: The Case of Linköping and Berzelius Science Park. European Planning Studies, 15, 1027-1045.

FERREIRA, J. J., RATTEN, V. \& DANA, L.-P. 2017. Knowledge spillover-based strategic entrepreneurship. International Entrepreneurship and Management Journal, 13, 161-167.

FISCHER, M. M. \& VARGA, A. 2003. Spatial knowledge spillovers and university research: Evidence from Austria. The Annals of Regional Science, 37, 303-322. 


\section{Bridging the chasm? Exploring the Effect of the University Context on Knowledge Exchange}

FITJAR, R. D. \& GJELSVIK, M. 2018. Why do firms collaborate with local universities? Regional Studies, 1-12.

FOSS, L. \& GIBSON, D. 2015. The Entrepreneurial University: Context and Institutional Change.

FRANCO, M. \& HAASE, H. 2015. University-industry cooperation: Researchers' motivations and interaction channels. Journal of Engineering and Technology Management, 36, 41-51.

GERMAIN-ALARMATINE, E. 2018. Transitioning from an economic to a broader social impact: A case study of a Swedish university. (RUNIN Working Paper Series; Vol. 2018, No. 01).

GODDARD, J. B. \& CHATTERTON, P. 1999. Regional Development Agencies and the Knowledge Economy: Harnessing the Potential of Universities. Environment and Planning $C$ : Government and Policy, 17, 685-699.

GULBRANDSEN, M. \& SLIPERSAETER, S. 2007. "The Third Mission and the Entrepreneurial University Model," Chapters, in: Universities and Strategic Knowledge Creation, chapter 4 Edward Elgar Publishing. .

GUNASEKARA, C. 2006. Reframing the Role of Universities in the Development of Regional Innovation Systems. The Journal of Technology Transfer, 31, 101-113.

HOMMEN, L., DOLOREUX, D. \& LARSSON, E. 2006. Emergence and Growth of Mjärdevi Science Park in Linköping, Sweden. European Planning Studies, 14, 1331-1361.

JONSSON, L., BARALDI, E., LARSSON, L.-E., FORSBERG, P. \& SEVERINSSON, K. 2015. Targeting Academic Engagement in Open Innovation: Tools, Effects and Challenges for University Management. Journal of the Knowledge Economy, 6, 522-550.

KEMPTON, L., GODDARD, J., EDWARDS, J., HEGYI, F. B. \& ELENA-PEREZ, S. 2014. Universities and Smart Specialisation. JRC Technical reports; S3 Policy Brief Series JRC85508. Seville: Institute for Prospective and technological Studies, Joint Research Centre.

LAMBOOY, J. 2004. The transmission of knowledge, emerging networks, and the role of universities: An evolutionary approach. European Planning Studies, 12, 643-657.

MUSCIO, A. \& VALLANTI, G. 2014. Perceived Obstacles to University-Industry Collaboration: Results from a Qualitative Survey of Italian Academic Departments. Industry and Innovation, 21, 410-429.

NOOTEBOOM, B. 2002. Trust: Forms, Foundations, Functions, Failures and Figures, Edward Elgar, Cheltenham.

OECD 1999. The Response of Higher Education Institutions to Regional Needs. Paris: Centre for Educational Research and Innovation, Programme on Institutional Management in Higher Education. Accessed 16.10.19.

OECD 2007. Higher Education and Regions: Globally Competitive, Locally Engaged. Paris: OECD. Accessed 16.10.19.

PERKMANN, M., KING, Z. \& PAVELIN, S. 2011. Engaging excellence? Effects of faculty quality on university engagement with industry. Research Policy, 40, 539-552.

PERKMANN, M., TARTARI, V., MCKELVEY, M., AUTIO, E., BROSTRÖM, A., D'ESTE, P., FINI, R., GEUNA, A., GRIMALDI, R., HUGHES, A., KRABEL, S., KITSON, M., LLERENA, P., LISSONI, F., SALTER, A. \& SOBRERO, M. 2013. Academic engagement and commercialisation: A review of the literature on university-industry relations. Research Policy, 42, 423-442.

PINHEIRO, R., LANGA, P. V. \& PAUSITS, A. 2015. The institutionalization of universities' third mission: introduction to the special issue. European Journal of Higher Education, 5, 227232. 


\section{Bridging the chasm? Exploring the Effect of the University \\ Context on Knowledge Exchange}

PLEWA, C., KORFF, N., JOHNSON, C., MACPHERSON, G., BAAKEN, T. \& RAMPERSAD, G. C. 2013. The evolution of university-industry linkages-A framework. Journal of Engineering and Technology Management, 30, 21-44.

POLANYI, M. 1967. The Tacit Dimension, London: Routledge and Kegan Paul.

RÀFOLS, I. 2017. There's no silver bullet for measuring societal impact 2017].

REGENERIS CONSULTING 2017. The Social, Cultural \& Economic Contribution of the University of Lincoln - A Final Report (www.regeneris.co.uk).

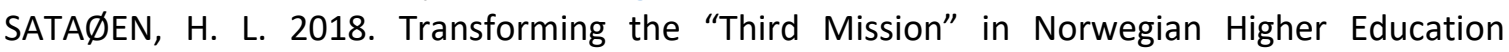
Institutions: A Boundary Object Theory Approach. Scandinavian Journal of Educational Research, 62, 52-67.

SAUNDERS, M., LEWIS, P. \& THORNHILL, A. 2016. Research Methods for Business Students, Harlow: Pearson.

SCHILLEBEECKX, S. J. D., CHATURVEDI, S., GEORGE, G. \& KING, Z. 2016. WHAT DO I WANT? THE EFFECTS OF INDIVIDUAL ASPIRATION AND RELATIONAL CAPABILITY ON COLLABORATION PREFERENCES. Strategic Management Journal, 37, 1493-1506.

SHAW, J. K. \& ALLISON, J. 1999. The Intersection of the Learning Region and Local and Regional Economic Development: Analysing the Role of Higher Education. Regional Studies, 33, 896-902.

SIEGEL, D. S., WALDMAN, D. \& LINK, A. 2003. Assessing the impact of organizational practices on the relative productivity of university technology transfer offices: an exploratory study. Research Policy, 32, 27-48.

STUCK, J., BROEKEL, T. \& REVILLA DIEZ, J. 2016. Network Structures in Regional Innovation Systems. European Planning Studies, 24, 423-442.

TARTARI, V., PERKMANN, M. \& SALTER, A. 2014. In Good Company: The Influence of Peers on Industry Engagement by Academic Scientists. Research Policy, Forthcoming. Available at SSRN: https://ssrn.com/abstract=1598456 or http://dx.doi.org/10.2139/ssrn.1598456

TORRE, A. 2008. On the Role Played by Temporary Geographical Proximity in Knowledge Transmission. Regional Studies, 42, 869-889.

TRIPPL, M. 2013. Scientific Mobility and Knowledge Transfer at the Interregional and Intraregional Level. Regional Studies, 47, 1653-1667.

VALLANCE, P., BLAŽEK, J., EDWARDS, J. \& KVĚTOŇ, V. 2018. Smart specialisation in regions with less-developed research and innovation systems: A changing role for universities? Environment and Planning C: Politics and Space, 36, 219-238.

VLAJCIC, D., MARZI, G., CAPUTO, A. \& DABIĆ, M. 2019. The role of geographical distance on the relationship between cultural intelligence and knowledge transfer. Business Process Management Journal, 25, 104-125.

VORLEY, T. \& NELLES, J. 2009. Building Entrepreneurial Architectures: A Conceptual Interpretation of the Third Mission. Policy Futures in Education, 7, 284-296.

WILSON, J. R. 2014. Essentials of Business Research, A guide to doing you research project, London, Sage publications Ltd.

YIN, R. K. 1984. Case study research: design and methods, Sage Publications.

YIN, R. K. 2002. Case Study Research - Design and Methods, London, Sage Publications.

ZAHLE, J. 2016. Methodological Holism in the Social Sciences. The Stanford Encyclopedia of Philosophy, 19. 